\title{
ENERGY USE PATTERN AND SENSITIVITY ANALYSIS OF RICE PRODUCTION: ACASE STUDY OF GUILANE PROVINCE OF IRAN
}

\author{
SEYYED HASSAN PISHGAR, S. RAFIEE ${ }^{1}$ and P. SEFEEDPARI \\ Department of Agricultural Machinery Engineering, Faculty of Agricultural Engineering and Technology, \\ University of Tehran, Karaj, Iran \\ ${ }^{1}$ Department of Agricultural Machinery Engineering, Faculty of Agricultural Engineering and Technology, \\ University of Tehran, Karaj, Iran \\ Corresponding author: s.hassan.pishgar@gmail.com
}

(Received 3 November, 2010; accepted 31 March, 2011)

\begin{abstract}
Rice is one of the most important crop supplying the world's population's food. Because of the direct links between energy and crop yields, and food supplies, rice energy analysis is essential. The objective of this study was to evaluate the energy balance between inputs and outputs of rice production in Guilane Province of Iran. Data were collected from 105 rice farmers with face to face questionnaire. A total energy input and output of 39.3 and $60.3 \mathrm{G}$ $\mathrm{J} \mathrm{ha}^{-1}$ was observed. Fertiliser and fuel were the highest energy inputs with amount of 14.1 and $11.6 \mathrm{G} \mathrm{J} \mathrm{ha}^{-1}$, followed by electricity and seed with 5.2 and $3.1 \mathrm{G} \mathrm{J} \mathrm{ha}^{-1}$, respectively. Energy use efficiency, energy productivity, specific energy and net energy were $1.57,0.09,11.20$ and $21 \mathrm{G} \mathrm{J} \mathrm{ha}^{-1}$, respectively. The share of non-renewable energy was almost $89 \%$, while the direct and indirect energy usage based on inputs was approximately equal (49 and $51 \%$, respectively). The econometric model showed that fuel and machinery had a significant effect on rice yield. The marginal physical productivity (MPP) value of fuel and machinery was 0.93 and 0.23 , respectively. The

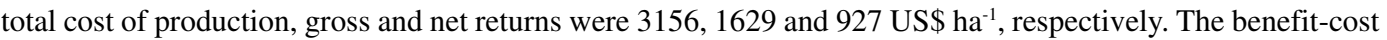
ratio was calculated to be 1.29 .
\end{abstract}

Key Words: Energy ratio, fuel, renewable energy

\section{RÉSUMÉ}

Le riz est parmi d'importantes cultures qui fournissent de la nourriture aux populations du monde. A cause des liens directs entre l'énergie et les rendements de cultures, l'analyse de l'énergie pour le riz est primordial. L'objectif de cette étude était d'évaluer la balance énergétique entre apports et sorties de la production du riz dans la Province de Guilane en Iran. De données étaient recuillies de 105 riziculteurs à l'aide d'un questionnaire face à face. Un total d'apport et sortie d'énergie de 39.3 et $60.3 \mathrm{G} \mathrm{J} \mathrm{ha}^{-1}$ était respectivement observé. Les fertilisants et le carburant constituaient un apport plus élevé d'énergie de l'ordre de 14.1 et $11.6 \mathrm{G} \mathrm{J} \mathrm{ha}^{-1}$ suivis de l'électicité et semence avec 5.2 et $3.1 \mathrm{G} \mathrm{J} \mathrm{ha}^{-1}$, respectivement. L'utilisation efficiente de l'énergie, la productivité de l'énergie, l'énergie spécifique et l' énergie nette étaient de 1.57, 0.09, 11.20 et $21 \mathrm{G} \mathrm{J} \mathrm{ha}^{-1}$, respectivement. La part de l'énergie non renouvelable était d'environ $89 \%$, pendant que l'usage direct et indirect de l'énergie basé sur les apports était approximativement égal (49 et 51\%, respectivement). Le modèle économétrique avait montré que le carburant et les machines avaient 0.93 et 0.23 , respectivement. Le coût total de production, le gros et le revenu net étaient de 3156, 1629 et 927 US\$ $\mathrm{ha}^{-1}$, respectivement. Le rapport coût-bénéfice calculé était de 1.29.

Mots Clés: Rapport énergétique, carburant, énergie renouvelable 


\section{INTRODUCTION}

Rice (Oryza sativa) is the most important staple food for the large part of the world's human population, especially in East, South, Southeast Asia, the Middle East, Latin America and the West Indies. The worldwide average yield of rice in 2007 was 4.15 tonnes per hectare (FAO, 2008). The annual production of rice in Iran was more than 2.2 million metric tonnes in 2008 (Anonymous, 2009). The province of Guilan with $34.2 \%$ of rice production is one of the main rice producing areas in Iran. In order to sustain agricultural production, effective energy use is required, since it provides ultimate financial saving, preserves fossil resources and reduces environment distortion (Demircan et al., 2006).

Agriculture is a process of energy conversion; the conversion of solar energy into food, feed and fiber through photosynthesis (Stout, 1990). Energy use in agricultural production has become more intensive due to the use of fossil fuel, chemical fertilisers, pesticides, machinery and electricity to provide substantial increases in food production. However, more intensive energy use has brought some important human health and environment problems. Thus efficient use of inputs has become important in terms of sustainable agricultural production (Yilmaz et al., 2005).

Energy requirements in agriculture are divided into two groups, direct and indirect. Direct energy is required to perform various tasks related to crop production processes such as land preparation, irrigation, intercultural, threshing, harvesting and transportation of agricultural inputs and produce (Singh, 2000). Direct energy is directly used at farms and on fields. Indirect energy, on the other hand, consists of the energy used in the manufacture, packaging and transport of fertilisers, pesticides, seed and farm machinery (Kennedy, 2000). Energy use patterns and the contribution of energy inputs vary depending on farming systems, cropping season and farming conditions. Considerable work has been done on the use of energy in agriculture with respect to efficient and economic uses for sustainable production (Yaldiz et al., 1993).

It has been realised that crop yields and food supplies are directly linked to energy (Stout,
1990). The main objective in agricultural production is to increase yield and decrease costs. In this respect, the energy budget is important. Energy budget is the numerical comparison of the relationship between inputs and out-put of a system in terms of energy (Gezer et al., 2003). Substantial research has been conducted on energy and economic analysis to determine the energy efficiency of different crop production practices in the developed countries (Singh and Mittal, 1992; Kuesters and Lammel, 1999; Mandal et al., 2002; Ozkan et al., 2004; Canakci et al., 2005; Hatirli et al., 2005; Jianbo, 2006; Çetin and Vardar, 2008). However, very few studies have been published on energy and economic analysis of rice crop with respect to Iran.

Khan et al. (2009) studied energy use patterns and the relationship between energy inputs of two regimes of rice cultivation (Bullock Operated Farms (BOF) and Tractor Operated Farms (TOF) in Dera Ismail Khan, District of Pakistan. Consumption of animal energy on BOF was more than TOF due to heavy use of animal energy in land preparation and output-input ratio on BOF (6.32) was higher than TOF (4.16). Gajaseni (1995) analysed energy usage of transplanting and direct seeding systems of wetland rice systems in Thailand. The output-input ratio was 4.5 for the transplanting system and 2.7 for the direct seeding system.

The aim of this study was to determine the energy use efficiency for the rice production in Iran.

\section{MATERIALS AND METHODS}

This study was done in Langroud city of Guilane Province, Iran in 2008-2009 production years. Guilan Province was selected because of its high rice production area (34\% of country area) (Anonymous, 2009). The data were collected using a face-to-face questionnaire from 105 farmers growing sole rice. The sample size was determined using a stratiûed random sampling technique (Yamane, 1967).

Using the socio-economic structures of the farms, the inputs and the energy requirements of each input were collected. The output was rice and inputs were machinery, human labour, 
chemical fertilisers, diesel fuel, pesticides and electricity. The energy consumption of all inputs was calculated using energy equivalents in Table 1. The labour energy was calculated by multiplying the number of man-hours by estimated power rating of human labour (Table 1). Other inputs like fertilisers, seed and biocides were transformed to energy values by multiplying the quantity of the inputs by the energy equivalent of each input. To prepare water for irrigation, diesel fuel and electrical pump were used so irrigation energy was included in fuel energy. Machinery energy was estimated using Equation 1.

$\mathrm{ME}=\mathrm{ExGxT}$

Where $M E$ is the machinery energy (MJ), $E$ the production energy of machine (Table 1 ), $G$ the weight of machine $(\mathrm{kg})$, and $T$ is the economic life of machine (year).

Input energy was also classified into direct and indirect, and renewable and nonrenewable forms. The direct energy (DE) included human,

TABLE 1. Energy equivalents of inputs and output in rice production

\begin{tabular}{lll}
\hline Inputs (unit) & Energy equivalent $\left(\mathrm{MJ} \mathrm{unit}^{-1}\right)$ & Reference/source \\
\hline
\end{tabular}

\section{A. INPUTS}

\section{Machinery}

Tractor and self-propelled ( $\mathrm{kg} \mathrm{a}$ )

Stationary equipment $(\mathrm{kg} \mathrm{a}) \quad 8-10$

Implement and machinery (kg a*) 6-8

Labour

Male (hr)

Female (hr)

Fuel

Diesel $(\mathrm{kg})$

Gasoline $(\mathrm{L})$

47.8

Natural gas $\left(\mathrm{m}^{3}\right)$

Electricity (kW hr)

Fertiliser

$\mathrm{N}(\mathrm{kg})$

$\mathrm{P}_{2} \mathrm{O}_{5}(\mathrm{~kg})$

$\mathrm{K}_{2} \mathrm{O}(\mathrm{kg})$

Biocide

Insecticide (kg)

Herbicide (kg)

Fungicide (kg)

Seed

46.3

49.5

12

78.1

17.4

13.7

229

85

115

14

\section{$6-8$}

\section{B. OUTPUTS}

Rice (kg)

Kitani, 1999

Kitani, 1999
Kitani, 1999

Kitani, 1999

Kitani, 1999

Singh, and Mittal, 1992

Singh, and Mittal, 1992

Kitani, 1999

Kitani, 1999

Kitani, 1999

Kitani, 1999

Kitani, 1999

Kitani, 1999

Kitani, 1999

Kitani, 1999

Kitani, 1999

Kitani, 1999

$a^{*}$ : economic life of machine (year) 
diesel, water and electricity energy that was used in the production process and; indirect energy (IDE) consisted of machinery, pesticide, seed and fertiliser. On the other hand, renewable energy (RE) consisted of human, seed, water and animal, and non-renewable energy (NRE) included machinery, electricity, diesel, biocide and fertiliser (Singh et al., 2003).

Following the calculation of energy inputs and output values, the energy ratio (energy use efficiency), energy productivity, specific energy and net energy were calculated using the procedure outlined by Demircan et al. (2006).

Cobb-Douglas function was used to evaluate statistical significance. Cobb-Douglas function has been used by others to examine the relationship between energy inputs and yield (Singh et al., 1998; Singh et al., 2003). CobbDouglas production function is expressed as:

$\mathrm{Y}=\mathrm{f}(\mathrm{x}) \exp (\mathrm{u})$

Eq. (3) can be linearised and expressed in the following form:

$\ln Y_{i}=\ln \beta_{0}+\sum_{j=1}^{n} \beta_{j} \ln \left(X_{i j}\right)+e_{i} \quad i=1,2, \ldots, n$

where $Y_{i}$ denotes the yield of the $i$ th farmer, $X_{i j}$ the vector of inputs used in the production process, $\ln \beta_{0}$ the constant term, $\beta_{j}$ represent coefficients of inputs which are estimated from the model; and $e_{i}$ is the error term. In this study with assumption that, when the energy input is zero, the crop production is also zero, Eq. (2) becomes shorter to Eq. (3):

$\ln Y_{i}=\sum_{j=1}^{n} \beta_{j} \ln \left(X_{i j}\right)+e_{i} \quad i=1,2, \ldots, n$

With the assumption that yield is a function of inputs energy Eq.(4) can be expanded to Eq.(5);

$\ln Y_{i}=\beta_{1} \ln \left(X_{1}\right)+\beta_{2} \ln \left(X_{2}\right)+\beta_{3} \ln \left(X_{3}\right)+\beta_{4} \ln \left(X_{4}\right)+\beta_{5} \ln \left(X_{5}\right)+\beta_{6}$

$\ln \left(X_{6}\right)+e_{i}$
Where $X_{1}$ is machinery energy, $X_{2}$ fuel energy, $X_{3}$ labour energy, $X_{4}$ fertiliser energy, $X_{5}$ biocide energy and $X_{6}$ seed energy.

In addition to the influence of each energy inputs on rice yield, Cobb-Douglas function was utilised to evaluate the impact of direct, indirect, renewable and noun-renewable forms of energy on rice yield as a following forms

$\ln Y_{i}=y_{1} \ln (D E)+y_{2} \ln (I D E)+e_{i}$

In $\mathrm{Y}_{\mathrm{i}}=\delta_{1} \operatorname{In}(\mathrm{RE})+\delta_{2} \operatorname{In}(\mathrm{NRE})+\mathrm{e}_{\mathrm{i}}$

Where $Y_{i}$ denotes the yield of the $i$ th farmer, $D E, I D E, R E$ and NRE are direct, indirect, renewable and noun-renewable energy that are used for rice production respectively, $Y_{i}$ and $\delta_{i}$ are the coefficients of variables and $e_{i}$ is the error term. Eqs.(5)-(7) were estimated using ordinary least square(OLS) technique.

To analyse the sensitivity of energy inputs on rice yield, MPP method based on the response coefficients of inputs was used. MPP factors express the changes of output with a unit change of input, while other inputs are fixed in their geometric mean value (Singh et al., 2004). A positive value of MPP indicated with an increase in input value, output value will increase and a negative value of MPP indicates with increasing in input value, output value will decrease.

The MPP value of each inputs, $\alpha_{i j}$ was utilised following Gündogmus (2006) and Singh et al. (2004).

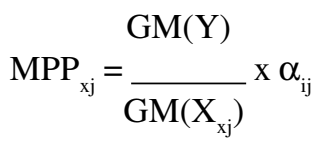

Where $\mathrm{MPP}_{\mathrm{xj}}$ is marginal physical productivity of $j$ th input, $\alpha i j$ regression coefficient of $j$ th input, $G M(Y)$ geometric mean of crop yield and $G M\left(X_{x j}\right)$ geometric mean of $j$ th input energy. Energy inputs and rice yield information were analysed using the Statistical Package for the Social Sciences 
(SPSS) and Shazam9.0 software programme and Eqs. (4) - (7) were calculated.

\section{RESULTS AND DISCUSSION}

Energy analysis. Total energy used as inputs was 39,333.36 $\mathrm{MJ} \mathrm{ha}^{-1}$ (Table 2). Of all the inputs, the chemical fertiliser including $\mathrm{N}, \mathrm{P}_{2} \mathrm{O}_{5}$ and $\mathrm{K}_{2} \mathrm{O}$ had the biggest share of total energy with $36 \%$. The result was similar to that of Khan et al. (2009) where fertiliser had the highest consumption among all inputs in rice production. With the lack of knowledge, most Iranian farmers do not know proper amount of fertiliser needed by the crop. With this problem and subsidised price, a large amount of fertiliser is used. According to Singh et al. (1998), energy used in the production of chemical fertilisers accounted for about $40 \%$ of total energy in agricultural production in developed countries.

Fertiliser energy is followed by fuel energy, with the share of $29 \%$ of total energy inputs (Table 2). Fuel energy was mainly used for irrigation,

TABLE 2. Energy inputs and output in rice production in Iran

\begin{tabular}{lrc}
\hline Inputs & Total energy (MJ ha-1) & Percentage \\
\hline A. Inputs & & \\
Machinery & 395.55 & 1.01 \\
Labour & $1,314.81$ & 3.34 \\
Fuel & & \\
Diesel & $11,594.99$ & 29.48 \\
Natural gas & $1,257.38$ & 3.2 \\
Electricity & $5,220.57$ & 13.27 \\
Fertiliser & $14,066.3$ & 35.76 \\
& & \\
Biocide & & \\
Insecticide & 703.71 & 1.79 \\
Herbicide & $1,502.51$ & 3.82 \\
Fungicide & 180.98 & 0.46 \\
& & \\
Seed & $3,096.56$ & 7.87 \\
Total energy input & $39,333.36$ & \\
& & \\
B. Outputs & $60,341.9$ & \\
Rice & $60,341.9$ & \\
Total energy output & & \\
\hline
\end{tabular}

tractors and various machinery operations. Because of a large amount of water is pumped in rice production and due to the low price (U\$ $0.018390 \mathrm{~L}^{-1}$ ) of this input (due to subsidies), high consumption of fuel energy was observed.

Electricity with a share of $13 \%$, took the third position. Electricity was mainly utilised in postharvest operations. Due to conventional technology and old machineries, electricity was highly consumed in rice production. The share of biocide (insecticide, herbicide and fungicide) energy was $7 \%$. Herbicide had the highest consumption of chemicals (4\%), followed by insecticide and fungicide ( 2 and $1 \%$, respectively) (Table 2).

Due to low mechanisation, machinery energy consumption was $395.55 \mathrm{MJ} \mathrm{ha}^{-1}$ (share of $1 \%$ ); while the human power was $3 \%$ of total input energy. The data revealed the average yield of $3,500 \mathrm{~kg} \mathrm{ha}^{-1}$ and therefore, total output energy of rice production calculated was $60,341.90 \mathrm{MJ}$ ha $^{-1}$.

Table 3 shows energy indices of rice production and the forms of energy input as direct and indirect energy, and renewable and nonrenewable energy.

Energy ratio is one of the best energy indices that shows the efficiency of rice production. The results indicated that 1.57 was less than rice energy ratio in Pakistan (Khan et al., 2009). Energy productivity, specific energy and net energy of rice production were $0.09,11.20$ and $21,008 \mathrm{MJ} \mathrm{ha}^{-1}$, respectively. The energy ratio values greater than 1 illustrates that production is efficiency and the output energy value is higher than the input energy values. The result revealed 19,388 $\mathrm{MJ} \mathrm{ha}^{-1}(49 \%)$ and $19,946 \mathrm{MJ} \mathrm{ha}^{-1}(51 \%)$ for direct and indirect energy, respectively.

Renewable and nonrenewable energy were 4,411 and 34,922 $\mathrm{MJ} \mathrm{ha}^{-1}$, with share of 11 and $89 \%$, respectively. With these results, it is clear that in comparison with renewable energy, the portion of non-renewable energy was high. It is obvious that in research area, rice production depends on non-renewable energy such as fossil fuels. Using non-renewable sources of energy leads to production of more greenhouse gas (GHG) and GHG emissions speeds up the global warming. 
Regression results showed significant impacts of machinery and fuel energy on rice yield $(\mathrm{P}<0.05)$ (Table 4$)$. In addition, seed and biocide had significant impacts on rice yield. Other input such as labour and chemical fertiliser had no significant impacts on rice yield. Of all inputs, fuel had the highest impact (0.83), followed by machinery $(0.12)$ and biocide $(0.12)$ energy. From the regression results, with $10 \%$ increasing in fuel, labour and machinery energy, rice yield will increase 8.3 , 1.2 and $1.2 \%$, respectively.

The results of MPP indicated that $1 \mathrm{MJ}$ increase in fuel and machinery energy led to 0.93 and $0.23 \mathrm{~kg} \mathrm{ha}^{-1}$ increase in yield of rice, respectively. To validate Model 1 of CobbDouglas function, Durbin Watson test was performed (Hatirli et al., 2005). Model 1 analysis resulted 1.97 for Durbin Watson value i.e., there was no autocorrelation in the estimated model $(\mathrm{P}>0.05)$. The Model's coefficient of determination $\mathrm{R}^{2}$ was 0.99 .

The regression analyse was used to realise the relationship between rice yield and forms of energy (direct and indirect) (Table 5). It was evident that the impact of direct and indirect energy on rice yield was highly significant $(\mathrm{P}<0.01)$ at 0.40 and 0.14 , respectively.

From Table 5, the impacts of renewable and nonrenewable energy focus were -0.02 and 0.35 , respectively and between this two forms of energy non-renewable form was significant $(\mathrm{P}<0.01)$. By calculating the MPP value, it became obvious that consuming more (1 MJ)

TABLE 3. Energy Indices in rice production in Iran

\begin{tabular}{llcc}
\hline Item & Unit & Index & Percentage \\
\hline Energy ratio & - & 1.57 & - \\
Energy productivity & $\mathrm{kg} \mathrm{MJ}^{-1}$ & 0.09 & - \\
Specific energy & $\mathrm{MJ} \mathrm{kg}^{-1}$ & 11.2 & - \\
Net energy & $\mathrm{MJ} \mathrm{ha}^{-1}$ & 21,008 & - \\
& & & \\
Energy forms & & 19,388 & 49.3 \\
Direct energy & $\mathrm{MJ} \mathrm{ha}^{-1}$ & 19,946 & 50.7 \\
Indirect energy & $\mathrm{MJ} \mathrm{ha}^{-1}$ & 4,411 & 11.22 \\
Renewable energy & $\mathrm{MJ} \mathrm{ha}^{-1}$ & 34,922 & 88.78 \\
Non-renewable Energy & $\mathrm{MJ} \mathrm{ha}^{-1}$ & 39,333 & - \\
Total energy & $\mathrm{MJ} \mathrm{ha}^{-1}$ &
\end{tabular}

TABLE 4. Econometric estimation results

\begin{tabular}{|c|c|c|c|}
\hline Independent variable & Coefficient & t-Ratio & MPP \\
\hline \multicolumn{4}{|c|}{ Model 1: $\operatorname{In} Y_{i}=\beta_{1} \operatorname{In}\left(X_{1}\right)+\beta_{2} \operatorname{In}\left(X_{2}\right)+\beta 3 \operatorname{In}\left(X_{3}\right)+\beta_{4} \operatorname{In}\left(X_{4}\right)+\beta_{5} \operatorname{In}\left(X_{5}\right)+\beta_{6} \operatorname{In}\left(X_{6}\right)+e_{i}$} \\
\hline Machinery & 0.12 & $4.79^{*}$ & 0.23 \\
\hline Fuel & 0.83 & $21.56^{*}$ & 0.93 \\
\hline Labour & -0.03 & -0.46 & -0.05 \\
\hline Fertiliser & 0.07 & 1.56 & 0.08 \\
\hline Biocide & 0.12 & $1.72^{*+*}$ & 0.17 \\
\hline Seed & 0.11 & $2.39^{* *}$ & 0.15 \\
\hline Durbin Watson & 1.97 & & \\
\hline $\mathrm{R}^{2}$ & 0.99 & & \\
\hline
\end{tabular}

" significant at $1 \%$ level; " significant at $5 \%$ level; "* significant at $10 \%$ level 
TABLE 5. Econometric estimation results of different forms of energies in Iran

\begin{tabular}{lccc}
\hline Independent variable & Coefficient & t-Ratio & MPP \\
\hline Model 2: $\mathbf{I n} \mathbf{Y}_{\mathbf{i}}=\mathbf{y}_{\mathbf{1}} \mathbf{I n}(\mathbf{D E})+\mathbf{y}_{\mathbf{2}} \mathbf{I n}(\mathbf{I D E})+\mathbf{e}_{\mathbf{i}}$ & & \\
Direct & 0.4 & $7.08^{*}$ & 0.45 \\
Indirect & 0.14 & $4.37^{*}$ & 0.15 \\
Durbin Watson & 1.74 & & \\
$\mathrm{R}^{2}$ & 0.99 & & \\
& & & \\
Model 3: $\mathbf{I n} \mathbf{Y}_{\mathbf{i}}=\boldsymbol{\delta}_{\mathbf{1}} \mathbf{I n}(\mathbf{R E})+\boldsymbol{\delta}_{\mathbf{2}} \mathbf{I n}(\mathbf{N R E})+\mathbf{e}_{\mathbf{i}}$ & & -0.03 \\
& -0.02 & -0.79 & 0.36 \\
Renewable & 0.35 & $14.66^{*}$ & \\
Nonrenewable & 2.05 & & \\
Durbin Watson & 0.99 & \\
$\mathrm{R}^{2}$ &
\end{tabular}

"significant at $1 \%$ level

TABLE 6. Economic analysis of rice production in Iran

\begin{tabular}{|c|c|c|}
\hline Cost and return components & Unit & Value \\
\hline Yield & $\mathrm{kg} \mathrm{ha}^{-1}$ & 3,550 \\
\hline Sale price & US\$ kg-1 & 1.15 \\
\hline Gross value of production & US\$ ha-1 & $4,095.6$ \\
\hline Variable cost of production & US\$ ha-1 & $2,453.62$ \\
\hline Fixed cost of production & US\$ ha-1 & 702.27 \\
\hline Total cost of production & US\$ ha-1 & $3,155.89$ \\
\hline Total cost of production & US\$ kg-1 & 0.9 \\
\hline Gross return & US\$ ha-1 & $1,641.98$ \\
\hline Net return & US\$ ha-1 & 939.71 \\
\hline Benefit to cost ratio & - & 0.47 \\
\hline Productivity & $\mathrm{kg} \$^{-1}$ & 1.16 \\
\hline
\end{tabular}

non-renewable, direct and indirect energy led to more $\left(0.36,0.45\right.$ and $\left.0.15 \mathrm{~kg} \mathrm{ha}^{-1}\right)$ rice yield; while by using more (1 MJ) renewable energy, rice yield decreased (0.03). Durbin Watson values of Model 2 and 3 were 1.74 and 2.05, respectively $(\mathrm{P}<0.05)$. In addition, the model's coefficient of determination was 0.99 for two specified models (Table 5).

Economic analysis of rice production. Table 6 presents variable and fixed costs of US\$ 2453.62 and $702.27 \mathrm{ha}^{-1}$, with shares of 77 and $23 \%$, respectively. The gross value of rice production was US\$4082.5 $\mathrm{ha}^{-1}$. Total cost of production based on cultivated area and the mass of harvested rice was US\$ 3155.89 and $0.90 \mathrm{~kg}^{-1}$, respectively. The Gross (Total production value $\left.\left(\$ h^{-1}\right)\right)$ - Variable cost of production $\left.\left(\$ h^{-1}\right)\right)$ and net return (Total production value $\left(\$ \mathrm{ha}^{-1}\right)$ - Total production cost $\left.\left(\$ \mathrm{ha}^{-1}\right)\right)$ were 1628.88 and 926.61 $\$ \mathrm{ha}^{-1}$, respectively. The benefit-cost ratio of rice production was 1.29 , which was lower than those reported earlier (Mandal et al., 2002; Khan et al., 2009). The benefit-cost ratio value indicated that rice production has economic efficiency in the research area. Economic productivity was 1.12.

\section{REFERENCES}

Anonymous. 2009. Annual Agricultural Statistics. Ministry of Jihad-e-Agriculture of Iran. Available at URL: <http://www.maj.ir>.

Canakci, M., Topakci, M., Akinci, I. and Ozmerzi, A. 2005. Energy use pattern of some field crops and vegetable production: Case study for Antalya region, Turkey. Energy Conversion and Management 46:655-66.

Çetin, B. and Vardar, A. 2008. An economic analysis of energy requirements and input costs for tomato production in Turkey. Renewable Energy 33:428-433.

Demircan, V., Ekinci, K., Keener, H.M., Akbotat, D. and Ekinci, C. 2006. Energy and economic analysis of sweet cherry production in Turkey: A case study from 
Isparta Province. Energy Conversion and Management 47:1761-1769.

Food and Agriculture Organization (FAO), 2008. Available at URL:<www.fao.org $>$.

Gajaseni, J. 1995. Energy analysis of wetland rice systems in Thailand. Ecosystems and Environment 52:173-178.

Gezer, I., Acaroglu, M. and Haciseferogullari, H. 2003. Use of energy and labour in apricot in Turkey. Biomass Bioenergy 24(3):215-9.

Gündogmus, E. 2006. Energy use on organic farming: a comparative analysis on organic versus conventional apricot production on small holdings in Turkey. Energy Conversion Management 47:3351-9.

Guzmán, G.I. and Alonso, A.M. 2008. A comparison of energy use in conventional and organic olive oil production in Spain. Agric Syst 98:167-76.

Hatirli, S.A., Ozkan, B. and Fert, C. 2005. An econometric analysis of energy input-output in Turkish agriculture. Renewable and Sustainable Energy Reviews 9:608-623.

Hetz, EJ. 1998. Energy utilisation in fruit production in Chile. Agricultural Mechanisation Asia, Africa Latin America (AMA). 298(2):17-20.

International Rice Research Institute, 2009. Available at URL:<beta.irri.org $>$.

Jianbo, L. 2006. Energy balance and economic beneûts of two agro-forestry systems in northern and southern China. Agriculture, Ecosystem and Environment 116:255-262.

Kennedy, S. 2000. Energy use in American agriculture. Sustainable Energy. Term Paper 2000. Available at URL: <web.mit.edu/10.391J/ www/proceedings/Agriculture_Kennedy 2000.pdf >

Khan, M.A., Awan, I.U. and Zafar, J. 2009. Energy requirement and economic analysis of rice production in western part of Pakistan. Soil and Environment 28(1):60-67.

Kitani, O. 1999. CIGR Handbook of Agricultural Engineering. Vol. 5, Energy and Biomass Engineering, ASAE publication, St Joseph, MI., USA.

Kuesters, J. and Lammel, J. 1999. Investigations of the energy efûciency of the production of winter wheat and sugarbeet in Europe. European Journal of Agronomy 11:35-43.

Mandal, K.G., Saha, K.P., Ghosh, P.K., Hati, K.M. and Bandyopadhyay, K.K. 2002. Bioenergy and economic analysis of soybean-based crop production system in central India. Biomass and Bioenergy 23(5):337- 345.

Ozkan, B., Akcaoz, H. and Karadeniz, F. 2004. Energy requirement and economic analysis of citrus production in Turkey. Energy Conversion and Management 45:1821-30.

Singh, G., Singh, S. and Singh, J. 2004. Optimisation of energy inputs for wheat crop in Punjab. Energy Conversion and Management 45:453465.

Singh, H., Mishra, D., Nahar, N.M. and Ranjan, M. 2003. Energy use pattern in production agriculture of a typical village in arid zone India: Part II. Energy Conversion Management 44(7):1053-67.

Singh, J.M. 2000. On farm energy use pattern in different cropping systems in Haryana, India. Germany: International Institute of Management, University of Flensburg, Sustainable Energy Systems and Management, Master of Science thesis. University of Flensburg, Germany.

Singh, S., Singh, S., Mittal, J.P. and Pannu, C.J.S. 1998. Frontier energy use for the cultivation of wheat crop in Punjab. Energy Conversation Management 39(5/6):485-91.

Singh, S. and Mittal, J.P. 1992. Energy in Production Agriculture. Mittal Publications, New Delhi, India. 143 pp.

Stout, B.A. 1990. Handbook of Energy for World Agriculture. Elsevier Applied Science London, UK. pp. 21.

Yaldiz, O., Ozturk, H., Zeren, Y. and Bascetincelik, A. 1993. Energy usage in production of field crops in Turkey. $5^{\text {th }}$ International Congress on Mechanisation and Energy Use in Agriculture, 11-14-Oct. Kusadasi,Turkey.

Yamane, T. 1967. Elementary sampling theory. Prentice Hall Englewood Cliffs. New Jersey, USA.

Yilmaz, I., Akcaoz, H. and Ozkan, B. 2005. An analysis of energy use and input costs for cotton production inTurkey. Renewable Energy 30:145-155. 